\title{
Loss of PMS2 Expression
}

National Cancer Institute

\section{Source}

National Cancer Institute. Loss of PMS2 Expression. NCI Thesaurus. Code C163012.

A molecular abnormality indicating the absence of PMS2 protein. 